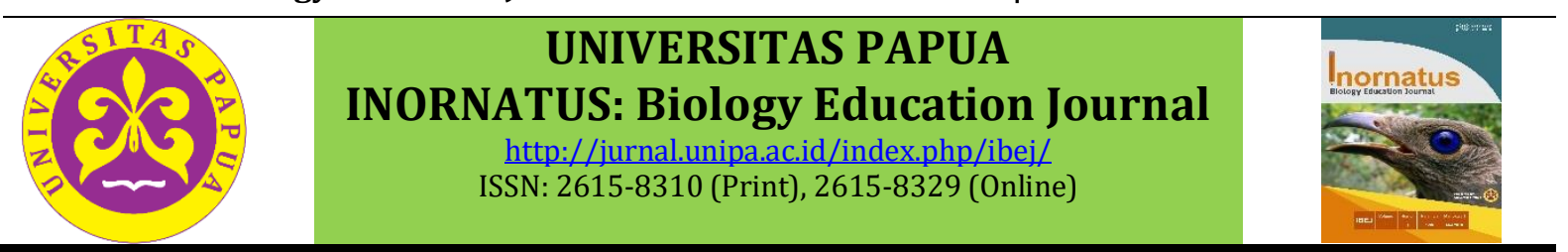

\title{
Student book based on Coastal natural resources: A development research to raise student pro-environmental character
}

\section{Buku siswa berbasis sumber daya alam pesisir: Penelitian pengembangan untuk meningkatkan karakter pro lingkungan siswa}

\author{
Yulan Kasim, Abubakar Sidik Katili, Elya Nusantari* \\ 1Universitas Negeri Gorontalo, Indonesia \\ *korespondensi penulis : elyanusantari@ung.ac.id
}

\begin{abstract}
The research aims to develop student books based on the potential of coastal areas to improve students' pro-environmental character. Research and development from Sugiyono was used to develop student book. as many as 10 students participated in the product trial. Two experts and one practitioner validated using a validation sheet. Measurement of pro-environmental character using pro-environmental character test. Analysis of pro-environmental characters using n-gain. The results showed that the student's book met the valid criteria (88.77\%), increased the pro-environmental character of students at the medium - high level (0.33 - 0.74), and received a very good response $(88 \%-100 \%)$ from the students. This research concludes that the student's book based on coastal natural resources meets the valid criteria, improves the character of the environmental profile and gets a very good response. Further research to test the effectiveness needs to be done through use trials.
\end{abstract}

Keywords: Student's book, character, coastal environment, pro-environment

\begin{abstract}
Abstrak
Riset bertujuan bertujuan untuk mengembangkan buku siswa berbasis potensi daerah pesisir untuk memperbaiki karakter pro lingkungan siswa. Penelitian dan pengembangan dari Sugiyono digunakan untuk mengembangkan buku siswa. sebanyak 10 siswa berpartisipasi dalam uji coba produk. Dua ahli dan satu praktisi melakukan validasi menggunakan lembar validasi. Pengukuran karakter pro lingkungan menggunakan tes karakter pro lingkungan. Analisis karakter pro lingkungan menggunakan n-gain. Hasil menunjukkan bahwa buku siswa memenuhi kriteria valid $(88,77 \%)$, meningkatkan karakter pro lingkungan siswa pada level sedang - tinggi $(0,33-0,74)$, dan mendapat respon sangat baik $(88 \%-100 \%)$ dari siswa. Riset ini menyimpulkan bahwa buku siswa berbasis sumber daya alam pesisir memenuhi kriteria valid, meningkatkan karakter pron lingkungan dan mendapat respon sangat baik. Riset selanjutnya untuk uji efektivitas perlu dilakukan melalui uji coba pemakaian.
\end{abstract}

Kata Kunci: Buku siswa, karakter, lingkungan pesisir, pro lingkungan

\section{Pendahuluan}

Sumber daya alam disepanjang pantai, khususnya terumbu karang dan padang lamun, memberikan banyak manfaat bagi kelangsungan hidup manusia karena berpotensi menyediakan berbagai sumber daya yang krusial bagi kelangsungan hidup manusia. Rusaknya terumbu karang disebabkan oleh berbagai aktivitas manusia yang merusak lingkungan, seperti penggunaan bahan peledak, pembuangan sampah di laut, penambangan karang untuk bahan bangunan, tambatan jangkar kapal, dan akibat sedimentasi. Hal ini dilakukan karena berkurangnya kesadaran manusia akan pentingnya menjaga lingkungan dan kurangnya rasa tanggung jawab terhadap lingkungan. Aktivitas manusia menciptakan penurunan kualitas lingkungan (Habibullah, Din, Chong, \& Radam, 
2016; Negev, Garb, Biller, Sagy, \& Tal, 2009), tetapi jika aktivitas positif maka menciptakan perbaikan lingkungan (Ballard, Dixon, \& Harris, 2017). Meningkatkan kepedulian terhadap lingkungan dapat dilakukan melalui proses pendidikan. Pendidikan karakter adalah salah satunya untuk memperbaiki karakter pro lingkungan. Karakter pro lingkungan harus dimulai sejak usia dini untuk menanamkan rasa tanggung jawab dan tanggung jawab pada diri siswa dalam hal menjaga lingkungan. Menawarkan pengalaman pribadi dapat meningkatkan karakter pro lingkungan (Chen \& Tsai, 2016; Warren \& Coghlan, 2016).

Orang akan memutuskan untuk melakukan tindakan pro lingkungan jika mereka merasa itu perlu dilakukan (Janmaimool \& Denpaiboon, 2016). Melakukan tindakan pro lingkungan akan terlaksana karena adanya contoh teladan yang diikuti oleh seseorang dari orang lain (Wesselink, Blok, \& Ringersma, 2017). Program pendidikan di sekolah yang memperkenalkan pendidikan karakter pro lingkungan dengan sendirinya akan menciptakan siswa yang memiliki karakter pro lingkungan (Fua, Rahma, Nurlila, \& Wekke, 2018). Nunez dan Clore (2017) yang menjelaskan pembelajaran dengan mengajarkan tentang masalah lingkungan seperti kerusakan ozon, penggunaan pupuk anorganik efek senyawa chlorofluorocarbon berkaitan dengan perbaikan sikap pro lingkungan siswa.

Pendidikan yang mengintegrasikan lingkungan dalam pengajar untuk menciptakan kesadaran siswa terhadap pro lingkungan (Obasoro, Oyinloye, \& Ilesanmi, 2013). Gorontalo mempunyai berbagai keragaman ekosistem yang ada di pesisir laut. Namun aktivitas manusia menyebabkan eksosistem tersebut terdegradasi (Katili, Ibrahim, \& Zakaria, 2017). Pengetahuan siswa terhadap lingkungannya adalah penting untuk diajarkan. Mengintegrasikan sumber daya lokal ke dalam pembelajaran salah satunya dengan memasukkan ke dalam buku siswa (Damopolii, Nunaki, Nusantari, \& Kandowangko, 2018). Buku siswa dibuat menarik agar siswa tertarik membacanya (Damopolii \& Nunaki, 2016). Ekosistem yang berada di area pesisir Gorontalo dapat dimanfaatkan untuk sumber belajar (Utina, Katili, Nusantari, \& Tamu, 2017) dan dapat meningkatkan karakter siswa untuk melindungi lingkungannya (Katili, Utina, Tamu, \& Nusantari, 2018). Dengan demikian riset ini bertujuan untuk mengembangkan buku siswa berbasis potensi daerah pesisir untuk memperbaiki karakter pro lingkungan siswa.

\section{Metode}

Penelitian ini mengikuti alur penelitian dan pengembangan dari Sugiyono, (2011). Namun artikel ini dibatasi pada tahap potensi dan masalah sampai uji coba produk. Sebanyak 10 siswa (kode S-1 - S-10) menjadi peserta dalam uji coba produk. Seluruh siswa berada pada kelas IV SD yang ada si pesisir pantai Gorontalo.

Perangkat utama riset ini adalah buku siswa berbasis sumber daya alam pesisir. Selain itu dikembangkan juga RPP atau rencana pelaksanaan pembelajaran, LKPD atau lembar kerja siswa dan tes untuk mengukur karakter pro lingkungan siswa. Validasi perangkat oleh dua ahli dan 1 praktisi menggunakan lembar validasi. Standar validasi mengikuti Akbar (2013). Analisis data karakter pro lingkungan menggunakan n-gain dari Hake (1998).

\section{Hasil dan Pembahasan}

Berdasarkan hasil analisis kebutuhan ditemukan bahwa siswa dan guru yang belum mengetahui sumber daya alam pesisir dan cara melestarikannya. Buku siswa yang tersedia di sekolah terutama materi sumber daya alam pesisir yang sesuai dengan karakteristik lingkungan dan dapat menanamkan karakter pro lingkungan masih kurang sehingga guru tidak mengajarkan materi tersebut pada siswa. Guru dan siswa 
mengharapkan tersedianya buku yang memaparkan tentang sumber daya alam pesisir khususnya materi tentang terumbu karang dan lamun dan bagaimana cara mengelola hasil sumber daya alam yang ada di lingkungan sekitar. Siswa ingin sekali belajar mengenai kondisi sumber daya alam pesisir.

Produk buku siswa yang dikembangkan terdiri atas tiga pokok bahasan yaitu tentang pengertian dan fungsi buku siswa, teknologi pengolahan hasil sumber daya alam pesisir, dan kaitan sumber daya alam dengan lingkungan dan masyarakat khususnya pada terumbu karang dan lamun. Buku siswa dilengkapi dengan LKPD pada setiap akhir materi bahasan yang bertujuan sebagai bahan diskusi bagi siswa untuk melihat level pemahaman siswa terhadap materi pada buku siswa. Buku siswa di desain dengan menggunakan microsoft word dengan tampilan layout berupa warna dan gambar yang menarik agar siswa dapat tertarik membaca buku siswa, selain itu dalam buku siswa terdapat gambar foto asli hasil sumber daya alam pesisir yang sesuai dengan potensi sumber daya alam pesisir yang ada di Gorontalo yang bertujuan agar siswa lebih mengenal sumber daya alam pesisir yang ada di daerahnya dan menjaga kelestarian sumber daya alam pesisir tersebut. Selain itu, buku siswa yang baru dikembangkan ini mencakup komponen yang dimaksudkan untuk membantu siswa dalam proses pembelajaran dan dalam memahami materi.

Validasi dilakukan dua ahli dan 1 praktisi. Validasi dilakukan terhadap buku siswa, LKPD, RPP, dan tes pengukur karakter pro lingkungan. Hasil validasi dihadirkan pada Gambar 1.

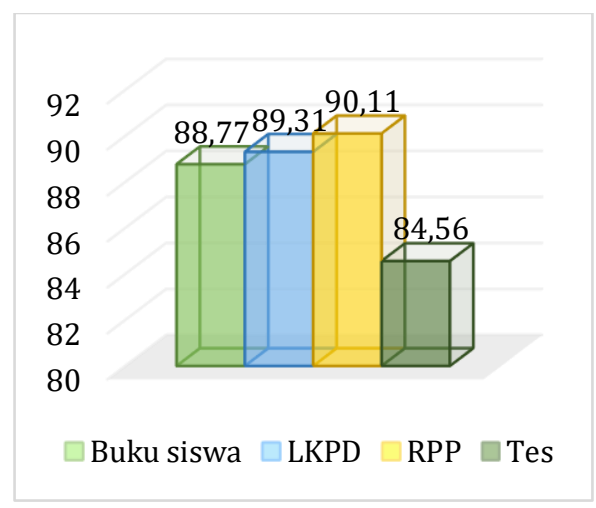

Gambar 1. Hasil validasi

Gambar 1 menghadirkan data validasi. Berdasarkan skor yang ditunjukkan pada gambar 1 mengindikasikan bahwa buku siswa, LKPD, RPP, dan Tes memenuhi kriteria valid dan dapat diimplementasikan. Beberapa revisi yang telah dilakukan terhadap perubahan buku siswa dihadirkan pada Gambar 2.

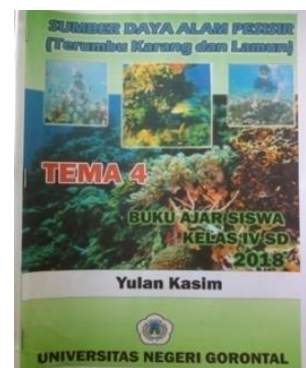

a. Desain awal

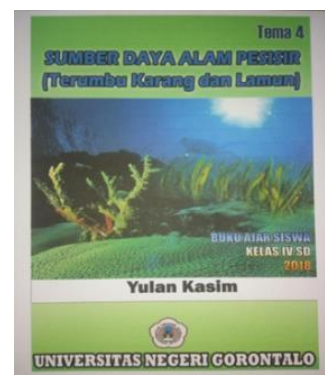

b. Desain setelah revisi

Gambar 2. Contoh desain buku siswa 


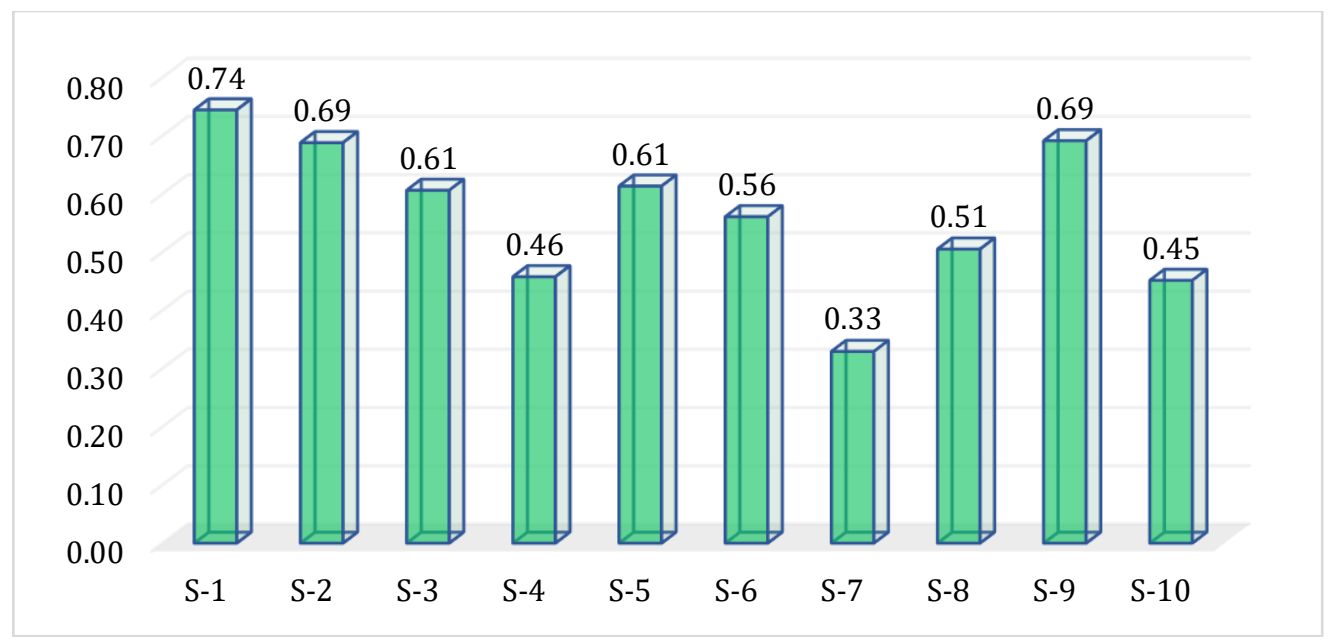

Gambar 3. Nilai n-gain karakter pro lingkungan

Berdasarkan data pada Gambar 3 mengindikasikan bahwa peningkatan karakter pro lingkungan siswa berada pada level sedang sampai tinggi. Tidak ada siswa yang mengalami peningkatan rendah sebelu dan sesudah penggunaan buku berbasis sumber daya alam pesisir. Begitu juga respon siswa yang dihadirkan pada Gambar 4. Semua siswa merespon dengan sangat baik penggunaan buku siswa berbasis sumber daya alam pesisir Gorontalo.

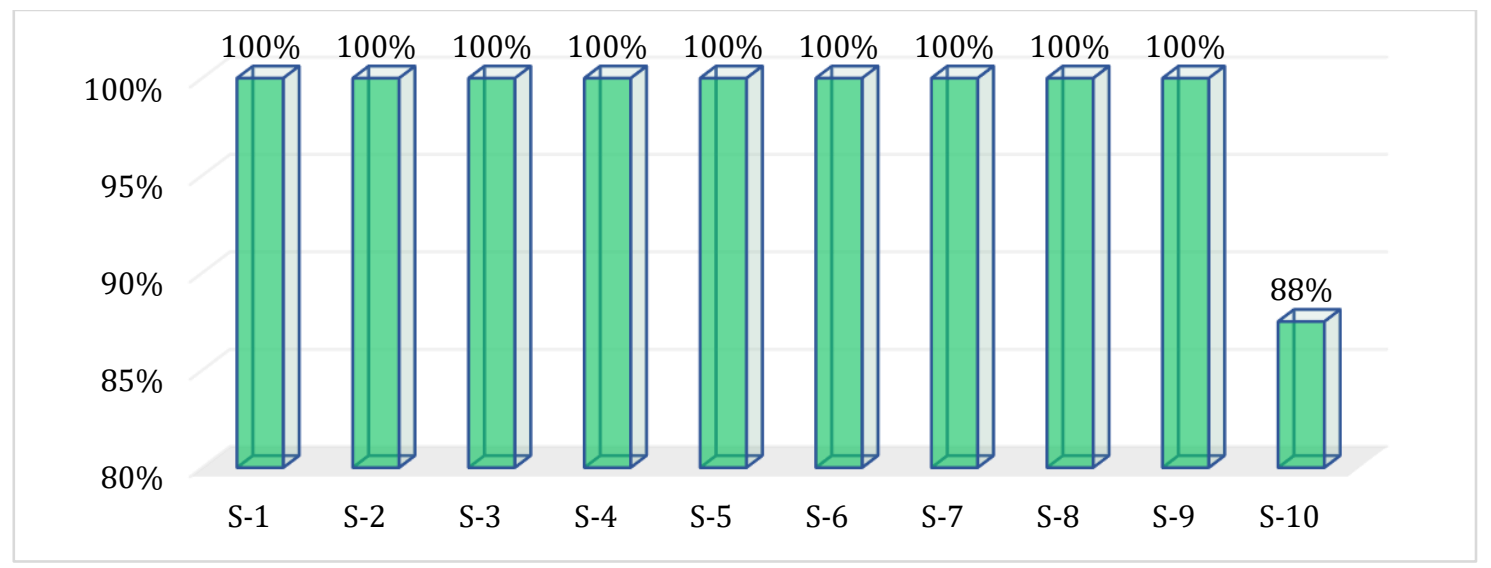

Gambar 4. Respon siswa terhadap pembelajaran

Berdasarkan riset pengembangan yang telah dilakukan, peneliti menemukan bahwa buku siswa memenuhi kriteria valid dan dapat diimplementasikan. Uji coba buku siswa berbasis sumber daya alam pesisir pantai Gorontalo menunjukkan bahwa dapat meningkatkan karakter pro-lingkungan siswa. informasi tetang keragaman eksosistem pesisir pantai Gorontalo membuat siswa dengan peka untuk melindungi lingkungannya. Yumusak, Sargin, Baltaci, dan Kelani, (2016) mengungkapkan bahwa siswa yang memiliki tingkat informasi tentang isu-isu lingkungan, mereka peka terhadap lingkungan dan cenderung melindunginya. Hasil ini juga senada dengan penelitian Shamuganathan dan Karpudewan, (2015), yang mengungkap bahwa perilaku yang bertanggung jawab terhadap lingkungan dipengaruhi oleh sikap dan keyakinan siswa terhadap perilaku dan pengetahuan tentang menjaga lingkungan dari masalah lingkungan. Dengan membelajarkan tentang pengetahuan lingkungan, siswa dengan sadar diri meningkatkan sikap mereka terhadap lingkungan (Mullenbach \& Green, 2018). 
Hasil pengembangan buku siswa berbasis sumber daya alam peisisir ini telah menghasilkan buku siswa yang valid dan dapat meningkatakan karakter pro lingkungan siswa melalui uji coba terbatas. Siswa memberikan respon yang sangat baik mengindikasikan bahwa buku yang dikembangkan dapat mereka gunakan dengan baik. Perangkat yang valid dan respon yang baik mengindikasikan pengembangan memenuhi untuk uji coba efektivitas (Bahtiar, Nunaki, \& Iwan, 2018; Posangi, Hasan, \& Dama, 2018). Uji coba pemakaian perlu dilakukan di riset berikutnya untuk mengetahui efektivitas buku yang dikembangkan.

\section{Simpulan}

Riset dan pengembangan ini telah berhasil mendesain buku siswa yang valid dan uji coba produk membuktikan dapat meningkatkan karakter pro lingkungan siswa. Respon siswa terhadap penggunaan buku terindikasi sangat baik. Riset ini menyimpulkan bahwa buku siswa berbasis sumber daya alam pesisir Gorontalo memenuhi kriteria valid, meningkatkan karakter pro lingkungan dan mendapat respon sangat baik dari siswa. Riset selanjutnya untuk mengetahui efektivitas buku ini perlu dilakukan.

\section{Referensi}

Akbar, S. (2013). Instrumen Perangkat Pembelajaran. Bandung: PT Remaja Rosdakarya.

Bahtiar, W. A., Nunaki, J. H., \& Iwan, I. I. (2018). Development of Biology Interactive Learning Multimedia on Animal Tissue Topic in The Class XI IPA in SMA Yapis Manokwari. Inornatus: Biology Education Journal, 1(1), 42-58. https://doi.org/10.30862/inornatus.v1i1.26

Ballard, H. L., Dixon, C. G. H., \& Harris, E. M. (2017). Youth-focused citizen science: Examining the role of environmental science learning and agency for conservation. Biological Conservation, 208, 65-75. https://doi.org/10.1016/j.biocon.2016.05.024

Chen, C.-L., \& Tsai, C.-H. (2016). Marine environmental awareness among university students in Taiwan: a potential signal for sustainability of the oceans. Environmental Education Research https://doi.org/10.1080/13504622.2015.1054266 $22(7)$,

958-977.

Damopolii, I., \& Nunaki, J. H. (2016). Pengembangan media pembelajaran komik IPA terpadu materi sistem pencernaan pada manusia. Pancaran Pendidikan, 5(3), 61-70.

Damopolii, I., Nunaki, J. H., Nusantari, E., \& Kandowangko, N. Y. (2018). Designing Teaching Material Oriented Towards Inquiry-Based Learning in Biology. Proceedings of the Mathematics, Informatics, Science, and Education International Conference (MISEIC 2018). Paris, France: Atlantis Press. https://doi.org/10.2991/miseic18.2018.1

Fua, J. La, Rahma, Nurlila, R. U., \& Wekke, I. S. (2018). Strategy of Islamic Education in Developing Character Building of Environmental Students in Indonesia. IOP Conference Series: Earth and Environmental Science, 175, 012149. https://doi.org/10.1088/1755-1315/175/1/012149

Habibullah, M. S., Din, B. H., Chong, C. W., \& Radam, A. (2016). Tourism and Biodiversity Loss: Implications for Business Sustainability. Procedia Economics and Finance, 35, 166-172. https://doi.org/10.1016/S2212-5671(16)00021-6

Hake, R. R. (1998). Interactive-engagement versus traditional methods: A six-thousandstudent survey of mechanics test data for introductory physics courses. American Journal of Physics, 66(1), 64-74. https://doi.org/10.1119/1.18809

Janmaimool, P., \& Denpaiboon, C. (2016). Evaluating determinants of rural Villagers' 
engagement in conservation and waste management behaviors based on integrated conceptual framework of Pro-environmental behavior. Life Sciences, Society and Policy, 12(1), 12. https://doi.org/10.1186/s40504-016-0045-3

Katili, A. S., Ibrahim, M., \& Zakaria, Z. (2017). Degradation level of mangrove forest and its reduction strategy in Tabongo Village, Boalemo District, Gorontalo Province, Indonesia. Asian Journal of Forestry, 1(1), 18-22. https://doi.org/10.13057/asianjfor/r010102

Katili, A. S., Utina, R., Tamu, Y., \& Nusantari, E. (2018). Management of coastal biodiversity based on social-cultural values in constructing conservation character education. Biodiversitas Journal of Biological Diversity, 19(5), 1763-1768. https://doi.org/10.13057/biodiv/d190524

Mullenbach, L. E., \& Green, G. T. (2018). Can environmental education increase studentathletes' environmental behaviors? Environmental Education Research, 24(3), 427444. https://doi.org/10.1080/13504622.2016.1241218

Negev, M., Garb, Y., Biller, R., Sagy, G., \& Tal, A. (2009). Environmental Problems, Causes, and Solutions: An Open Question. The Journal of Environmental Education, 41(2), 101-115. https://doi.org/10.1080/00958960903295258

Nunez, M. B., \& Clore, M. A. (2017). Environmental Literacy of K-10 Student Completers. International Journal of Environmental and Science Education, 12(5), 1195-1215. Retrieved from http://www.ijese.net/makale/1885.html

Obasoro, C., Oyinloye, O., \& Ilesanmi, A. (2013). The Importance of Environmental Education to Secondary Education Level in Akure South Local Government Area, Ondo State, Nigeria. African Research Review, 7(1), 298-306. https://doi.org/10.4314/afrrev.v7i1.20

Posangi, N. W., Hasan, A. M., \& Dama, L. (2018). Standardization of science process skills (SPS) assessment instruments in microbiology labs. Inornatus: Biology Education Journal, 1(1), 59-68. https://doi.org/10.30862/inornatus.v1i1.32

Shamuganathan, S., \& Karpudewan, M. (2015). Modeling Environmental Literacy of Malaysian Pre-University Students. International Journal of Environmental Science Education, 10(5), 757-771. https://doi.org/10.12973/ijese.2015.264a

Sugiyono. (2011). Metode penelitian pendidikan. Bandung: Alfabeta.

Utina, R., Katili, A. S., Nusantari, E., \& Tamu, Y. (2017). Coastal Ecosystems Capacity as a Study Material in Biology Learning in the Coastal Areas. Australian Journal of Basic and Applied Sciences, 11(13), 122-127. https://doi.org/10.22587/ajbas.2017.11.13.14

Warren, C., \& Coghlan, A. (2016). Using character strength-based activities to design proenvironmental behaviours into the tourist experience. Anatolia, 27(4), 480-492. https://doi.org/10.1080/13032917.2016.1217893

Wesselink, R., Blok, V., \& Ringersma, J. (2017). Pro-environmental behaviour in the workplace and the role of managers and organisation. Journal of Cleaner Production, 168, 1679-1687. https://doi.org/10.1016/j.jclepro.2017.08.214

Yumusak, A., Sargin, S. A., Baltaci, F., \& Kelani, R. R. (2016). Science \& Mathematics Teacher Candidates' Environmental Knowledge, Awareness, Behavior and Attitudes. International Journal \& Science Education, 11(6), 1337-1346. https://doi.org/10.12973/ijese.2016.347a 